\title{
PROBLEMATYKA ZASKARŻANIA ZARZĄDZENIA POKONTROLNEGO ORGANÓW INSPEKCJI OCHRONY ŚRODOWISKA
}

\section{ISSUES CONCERNING THE APPEAL AGAINST A POST-INSPECTION REGULATION OF ENVIRONMENTAL PROTECTION INSPECTION BODIES}

\section{STRESZCZENIE}

Przedmiotem artykułu jest omówienie problematyki zaskarżania do sądu administracyjnego zarządzenia pokontrolnego wydawanego

* Magister prawa, doktorant na Uniwersytecie Mikołaja Kopernika, asystent sędziego w Wojewódzkim Sądzie Administracyjnym w Olsztynie.

** Magister prawa, doktorant na Uniwersytecie Gdańskim, asystent sędziego w Wojewódzkim Sądzie Administracyjnym w Olsztynie. 
przez organy Inspekcji Ochrony Środowiska. Zważywszy na okoliczność, że przepisy ustawy o Inspekcji Ochrony Środowiska nie przewidują możliwości zaskarżenia zarządzenia pokontrolnego do organu wyższego stopnia, kwestia dopuszczalności sądowej oceny legalności powyższego aktu wydaje się istotna. $\mathrm{W}$ artykule przedstawiono procedurę wydawania zarządzenia pokontrolnego, omówiono jego charakter prawny oraz możliwość poddania tego aktu kontroli sądowej.

\section{Słowa kluczowe}

Inspekcja Ochrony Środowiska; zarządzenie pokontrolne; kontrola sądu administracyjnego; ochrona praw podmiotowych.

\section{ABSTRACT}

The subject of the article is the analysis of issues concerning the appeal to the administrative court against a post-inspection regulation issued by the Environmental Protection Inspection. Having regard to the fact that the provisions of the Act on the Inspection for Environmental Protection do not include a possibility of appeal against a post-inspection regulation to a higher administrative body, the issue of judicial admissibility of the legality of a post-inspection regulation seems to be important. The article also presents the procedure of issuing a post-inspection regulation, its legal character and the possibility of giving this act to the judicial review.

\section{Keywords}

Environmental Protection Inspection; post-inspection regulation; administrative court inspection; protection of subjective rights.

Kontrola, jako rodzaj działania, obejmuje z jednej strony sprawdzenie i ocenienie czegoś, formułowanie wniosków, ustalenie faktów, wgląd w działalność, zestawienie stanu faktycznego ze stanem wymaganym oraz ustalenie ewentualnych odstępstw ${ }^{1}$. Sformułowane na gruncie prawa administracyjnego liczne definicje kontroli akcentują jej ścisły związek z ustaleniem

1 Zob. Uniwersalny słownik języka polskiego, red. S. Dubisz, Warszawa 2003, t. 2, s. 431. 
okoliczności faktycznych, wskazaniem przyczyn ewentualnych rozbieżności oraz sformułowaniem zaleceń mających zapobiegać zjawiskom niepożądanym, stwierdzonym w toku czynności kontrolnych ${ }^{2}$. Kontrola nie może jednak ograniczać się wyłącznie do wykrywania nieprawidłowości, ale służyć ma stworzeniu warunków do ich skutecznego eliminowania w przyszłości. Stąd też bezpośrednim przejawem działań kontrolnych są przeróżne postulaty, uwagi, wnioski i inne formy zaleceń, które mają charakter niewładczy.

Jednym z organów administracji publicznej uprawnionym do kontroli prawidłowego korzystania ze środowiska jest Inspekcja Ochrony Środowiska. Zakres jej działania i podstawy funkcjonalne reguluje ustawa z dnia 20 lipca 1991 r. o Inspekcji Ochrony Środowiska ${ }^{3}$ (dalej jako: u.i.o.ś.).

W wielu wypadkach, po zakończeniu kontroli przez organy Inspekcji Ochrony Środowiska do kontrolowanego podmiotu adresowane jest zarządzenie pokontrolne ${ }^{4}$. Zarządzenie pokontrolne $^{5}$ stanowi swoisty akt działania administracji publicznej stwierdzający naruszenie konkretnego obowiązku prawnego dotyczącego ochrony środowiska ${ }^{6}$. Nie oznacza to jednak, że kontrolowany nie ma prawnej możliwości obrony polegającej na możliwości zakwestionowania zarządzenia pokontrolnego.

Celem niniejszego opracowania jest omówienie problematyki zaskarżania do sądu administracyjnego zarządzenia pokon-

2 Zob. J. Jagielski, Kontrola administracji publicznej, Warszawa 2007, s. $14-15$.

3 Dz.U. z 2007 r. Nr 44, poz. 287 ze zm.

4 W ocenie Głównego Inspektora Ochrony Środowiska zarządzenie pokontrolne stanowi najczęściej stosowane i skuteczne działanie pokontrolne. W 2011 r. organy inspekcji ochrony środowiska wydały 6538 zarządzeń pokontrolnych, [w:] Główny Inspektorat Ochrony Środowiska, Informacja o Realizacji Zadań Inspekcji Ochrony Środowiska w 2011 r., Warszawa 2012, s. 35. Publikowane: www.gios.gov.pl

5 Zdaniem W. Radeckiego zarządzenie pokontrolne jest podstawowym efektem przeprowadzonej kontroli - zob. W. Radecki. Ustawa o Inspekcji Ochrony Środowiska. Komentarz, Wrocław 2000, s. 47.

6 Tak też T. Czech, Zarządzenie pokontrolne organów Inspekcji Ochrony Środowiska, „Zeszyty Naukowe Sądownictwa Administracyjnego”, nr 3/2011, s. 93. 
trolnego wydawanego przez organy Inspekcji Ochrony Środowiska. Zważywszy bowiem na okoliczność, że przepisy u.i.o.ś. nie przewidują możliwości zaskarżenia zarządzenia pokontrolnego do organu wyższego stopnia, kwestia dopuszczalności sądowej oceny legalności ${ }^{7}$ powyższego aktu wydaje się istotna.

Przedstawiając zagadnienie dopuszczalności skargi do sądu administracyjnego na zarządzenie pokontrolne, należy w pierwszej kolejności przybliżyć w zarysie te regulacje prawne, które upoważniają organ Inspekcji Ochrony Środowiska do wydania zarządzenia pokontrolnego, jak też wyjaśnić jego charakter prawny.

Zgodnie z art. 1 u.i.o.ś „Inspekcja Ochrony Środowiska jest powołana do kontroli przestrzegania przepisów o ochronie środowiska oraz badania i oceny stanu środowiska". Art. 2 ust. 1 pkt 1 lit. „a” i „b” u.i.o.ś. stanowi, że „do zadań Inspekcji Ochrony Środowiska należy kontrola podmiotów korzystających ze środowiska w rozumieniu ustawy z dnia 27 kwietnia 2001 r. Prawo ochrony środowiska (Dz.U. z 2008 r. Nr 25, poz. 150, z późn. zm.) w zakresie: przestrzegania przepisów o ochronie środowiska, przestrzegania decyzji ustalających warunki korzystania ze środowiska oraz przestrzegania zakresu, częstotliwości i sposobu prowadzenia pomiarów wielkości emisji i jej wpływu na stan środowiska".

Stosownie do treści art. 3 pkt 20 ustawy Prawo ochrony środowiska (dalej jako: u.p.o.ś.) podmiotem korzystającym ze środowiska jest:

a) przedsiębiorca $\mathrm{w}$ rozumieniu art. 4 ustawy $\mathrm{z}$ dnia 2 lipca 2004 r. o swobodzie działalności gospodarczej (Dz.U. z 2007 r. Nr 155, poz. 1095 i Nr 180, poz. 1280) (osoba fizyczna, osoba prawna i jednostka organizacyjna niebędąca osobą prawną, której odrębna ustawa przyznaje

7 Kryterium kontroli wykonywanej przez sądy administracyjne określa art. 1 § 2 ustawy z dnia 25 sierpnia 2002 r. Prawo o ustroju sądów administracyjnych (Dz.U. nr 153, poz. 1269 ze zm.), który stanowi, że jest ona sprawowana pod względem zgodności z prawem, jeżeli ustawy nie stanowią inaczej. Mamy tu zatem do czynienia z zasadą praworządności (legalności) charakterystyczną dla całego systemu prawa. 
zdolność prawną - wykonująca we własnym imieniu działalność gospodarczą oraz wspólnicy spółki cywilnej w zakresie wykonywanej przez nich działalności gospodarczej), a także osoby prowadzące działalność wytwórczą $\mathrm{w}$ rolnictwie w zakresie upraw rolnych, chowu lub hodowli zwierząt, ogrodnictwa, warzywnictwa, leśnictwa i rybactwa śródlądowego oraz osoby wykonujące zawód medyczny w ramach indywidualnej praktyki lub indywidualnej specjalistycznej praktyki,

b) jednostka organizacyjna niebędąca przedsiębiorcą w rozumieniu ustawy z dnia 2 lipca 2004 r. o swobodzie działalności gospodarczej,

c) osoba fizyczna niebędąca podmiotem, o którym mowa w lit. a, korzystająca ze środowiska w zakresie, w jakim korzystanie ze środowiska wymaga pozwolenia.

W myśl art. 9 ust. 1 u.i.o.ś. zadania kontrolne wykonuje Główny Inspektor Ochrony Środowiska, wojewódzki inspektor ochrony środowiska oraz upoważnieni przez nich pracownicy Inspekcji Ochrony Środowiska, zwani dalej „inspektorami”.

$\mathrm{Z}$ art. 11 u.i.o.ś. wynika natomiast, że z czynności kontrolnych inspektor sporządza protokół, którego jeden egzemplarz doręcza kierownikowi kontrolowanej jednostki organizacyjnej lub kontrolowanej osobie fizycznej (ust. 1). Kierownik kontrolowanej jednostki organizacyjnej lub kontrolowana osoba fizyczna mogą wnieść do protokołu umotywowane zastrzeżenia i uwagi.

Artykuł 12 ust. 1 u.i.o.ś. stanowi, że „na podstawie ustaleń kontroli wojewódzki inspektor ochrony środowiska może ${ }^{8}$ :

1) wydać zarządzenie pokontrolne do kierownika kontrolowanej jednostki organizacyjnej lub osoby fizycznej;

2) wydać na podstawie odrębnych przepisów decyzję administracyjną;

3) wszcząć egzekucję jeżeli obowiązek wynika z mocy prawa lub decyzji administracyjnej".

8 Zgodnie z art. 22 u.i.o.ś. Główny Inspektor Ochrony Środowiska może podejmować wszelkie czynności należące do właściwości wojewódzkiego inspektora ochrony środowiska, jeśli uzna to za celowe ze względu na wagę lub zawiłość sprawy. 
Adresat zarządzenia pokontrolnego jest zobligowany do podjęcia działań wynikających z zarządzenia pokontrolnego, a w szczególności - jak stanowi to art. 12 ust. 2 u.i.o.ś. - ma obowiązek w terminie wyznaczonym w zarządzeniu pokontrolnym, poinformowania wojewódzkiego inspektora ochrony środowiska o zakresie podjętych i zrealizowanych działań służących wyeliminowaniu wskazanych naruszeń.

Z treści powyżej przytoczonych przepisów wynika, że zarządzenie pokontrolne, będące wyrazem interwencji właściwego organu, jest wydawane na podstawie ustaleń kontroli. W wyroku $^{9} \mathrm{z}$ dnia 25 marca 2008 r. $^{10}$ Wojewódzki Sąd Administracyjny w Opolu stwierdził, że „zarządzenie pokontrolne wydawane jest $\mathrm{w}$ razie stwierdzenia $\mathrm{w}$ wyniku przeprowadzonej kontroli naruszeń prawa i ma na celu wyeliminowanie tych naruszeń poprzez zobowiązanie do poinformowania o działaniach, jakie kontrolowana jednostka podjęła, aby dalsza jej działalność nie naruszała prawa (...) przysługujące organowi kompetencje w zakresie wydawania zarządzeń pokontrolnych nie mogą być przez organ wykorzystywane w celach instruktażowych, do bieżącego pouczania i przypominania o obowiązkach ciążących na kontrolowanej jednostce, a wynikających z przepisów prawa, gdyż służą wyłącznie w celu przeciwdziałania stwierdzonym w toku kontroli naruszeniom". Natomiast w ocenie T. Czecha ${ }^{11}$ zarządzeń pokontrolnych nie wydaje się, gdy w toku kontroli stwierdzono naruszenia, ale przed jej zakończeniem zostały one wyeliminowane oraz w sytuacji, gdy stan faktyczny stwierdzony w czasie kontroli nie wykazuje rozbieżności ze stanem postulowanym. Należy zgodzić się z tym Autorem, że wydanie zarządzenia pokontrolnego leży w sferze uznania administracyjnego organu Inspekcji Ochrony Środowiska (sformułowanie: „może wydać”), a więc nie jest to obligatoryjny element wieńczący procedurę

9 Wszystkie powołane w niniejszym opracowaniu orzeczenia wojewódzkich sądów administracyjnych, jak też orzeczenia Naczelnego Sądu Administracyjnego dostępne są w internetowej Centralnej Bazie Orzeczeń Sądów Administracyjnych pod adresem: www.orzeczenia.nsa.gov.pl.

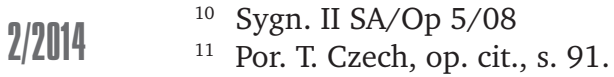


kontroli (kontrola może zakończyć się np. decyzją administracyjną). W terminie ustalonym $\mathrm{w}$ zarządzeniu pokontrolnym kontrolowany podmiot ma obowiązek poinformować organ ochrony środowiska o zakresie podjętych i zrealizowanych działań służących wyeliminowaniu wskazanych naruszeń ${ }^{12}$. Należy wobec powyższego przyjąć, że zalecenia zawarte z zarządzeniu pokontrolnym stanowią konsekwencję stwierdzonych w trakcie kontroli nieprawidłowości. Brak takich nieprawidłowości nie uzasadnia zatem wydawania zarządzenia pokontrolnego. Stąd istotne znaczenie dla oceny legalności wydanego zarządzenia ma stwierdzenie, czy wyniki kontroli dają podstawę do uznania, że kontrolowany podmiot narusza prawo. Zarządzenie pokontrolne nie jest tylko prostym „przypomnieniem” obowiązków wynikających z inny źródeł: przepisów lub decyzji, lecz „przypomnieniem" o obowiązkach naruszonych, nie służy zacytowaniu obowiązków strony, lecz zwraca uwagę na uchybienia ${ }^{13}$. Uchybienia takie stanowią oczywiście podstawę do wszczęcia i prowadzenia postępowania administracyjnego mającego na celu ich sankcjonowanie i w toku takiego postępowania strona może podważać zasadność zarzutów i wykazywać, że dopełniła ciążących na niej obowiązków. Twierdzenie bowiem, iż to wyłącznie organy Inspekcji Ochrony Środowiska mają monopol na ocenianie, czy zachowane są przepisy ochrony środowiska, a podmiot kontrolowany pozbawiony jest możliwości korzystania ze środków dowodowych, np.: ze świadków, oględzin, z opinii niezależnego biegłego, czy też przeprowadzenia dowodu przeciwko treści dokumentu, w tym tego, co stwierdzono w protokole z kontroli, wydaje się sprzeczne z konstytucyjnymi zasadami takimi, jak zasada praworządności czy też zasada ochrony

12 Zarządzenie pokontrolne musi nadawać się do wykonania zarówno przez samego adresata, jak i ewentualnie w drodze przymusu egzekucyjnego. Akcentuje się, że w ramach badania dopuszczalności egzekucji organ egzekucyjny powinien sprawdzić, czy obowiązek jest wykonalny, a jeżeli tak, to czy zobowiązany ma obiektywną możliwość jego wykonania - por. W. Piątek, A. Skoczylas, [w:] R. Hauser, A. Skoczylas, Postępowanie egzekucyjne w administracji. Komentarz, Warszawa 2011, s. 182.

13 Por. wyrok WSA w Gliwicach z dnia 9 września 2009 r., sygn. II SA/GL 126/09. 
praw obywatelskich. Niemniej jednak, w postępowaniu kontrolnym ciężar dowodu spoczywa na organie, który w tym zakresie obowiązany jest między innymi do przeprowadzenia z urzędu dowodów służących ustaleniu stanu faktycznego sprawy, wystąpienia do strony z żądaniem przedstawienia dowodów na poparcie jej twierdzeń, czy też wystąpienia do innych organów lub instytucji o udzielenie będących $\mathrm{w}$ ich posiadaniu informacji bądź udostępnienie dokumentów, mogących przyczynić się do wyjaśnienia istotnych dla sprawy okoliczności faktycznych, a kontrolowany podmiot nie może zastąpić organu administracji w wykonaniu tego obowiązku. Tym samym, już na etapie kontroli strona może negować zasadność jej wyników. Możliwość taką daje jej również dopuszczalność wniesienia skargi do sądu na zarządzenie pokontrolne.

Charakter prawny zarządzenia pokontrolnego nie budzi wątpliwości zarówno w literaturze przedmiotu, jak i w judykaturze, ponieważ zgodnie przyjmuje się, że będąc, tak jak decyzja, władczym aktem administracji, nie jest ono decyzją administracyjną. W ocenie T. Czecha ${ }^{14}$ za „władczym” charakterem zarządzenia pokontrolnego przemawiają przede wszystkim konsekwencje prawne jego niewykonania. Autor ten wskazuje, że na podstawie zarządzenia pokontrolnego zawiązuje się stosunek administracyjnoprawny, którego częścią jest obowiązek informacyjny ciążący na adresacie zarządzenia, jednakże w zarządzeniu pokontrolnym organ Inspekcji Ochrony Środowiska nie może na kontrolowany podmiot lub jego kierownika nałożyć bezpośredniego obowiązku podjęcia jakichkolwiek konkretnych działań, które zmierzałyby do usunięcia stwierdzonych naruszeń. Naruszenie powyższego obowiązku podlega sankcji karnej - jako wykroczenie - stosownie do art. 31a ust. 1 pkt 1 i 2 u.i.o.ś. Ponadto w zarządzeniu pokontrolnym organ Inspekcji Ochrony Środowiska jednostronnie - w sposób deklaratoryjny stwierdza, że na kontrolowanym podmiocie ciąży określony obowiązek prawny dotyczący ochrony środowiska i że doszło do 
jego naruszenia. Z kolei zdaniem B. Draniewicza ${ }^{15}$ penalizacja (obłożenie odpowiedzialnością wykroczeniową) niepoinformowania $\mathrm{w}$ terminie organu Inspekcji Ochrony Środowiska o zakresie wykonania zarządzenia pokontrolnego przesądza o jego „władczym” charakterze. Tak też wypowiedział się Naczelny Sąd Administracyjny ${ }^{16}$ wskazując, że „nie można zgodzić się z twierdzeniem, że niewykonanie zarządzeń nie wpływa w żaden sposób na prawa i obowiązki. Skoro zarządzenie pokontrolne stwierdza istnienie po stronie obywatela jakiegoś obowiązku, to jest działaniem władczym". Podobnie wypowiedział się WSA w Krakowie ${ }^{17}$ wyjaśniając, że zarządzenie pokontrolne, o którym mowa w art. 12 ust. 1 pkt 1 u.i.o.ś. jest aktem o charakterze władczym organu administracji publicznej, nakładającym na adresata określone obowiązki.

W orzecznictwie sądowoadministracyjnym dotyczącym powyższej kwestii, nie ma najmniejszych wątpliwości, że zarządzenie pokontrolne nie jest decyzją administracyjną. W wyro$\mathrm{ku}^{18}$ wydanym w sprawie II GSK 1009/08 NSA stwierdził, iż „z treści art. 12 ust. 1 pkt 1 i 2 u.i.o.ś. wynika jednoznacznie, że zarządzenie pokontrolne jest odrębną od decyzji administracyjnej prawną formą działania inspektora ochrony środowiska. Wydawanemu przez tego inspektora zarządzeniu pokontrolnemu, mimo że nie jest decyzją administracyjną, nie można odmówić charakteru aktu administracji publicznej, o jakim mowa w art. $3 \S 2$ pkt 4 ustawy z dnia 30 sierpnia 2002 r. Prawo o postępowaniu przed sądami administracyjnymi ${ }^{19}$, ponieważ ma ono bez wątpienia charakter władczy i rozstrzyga indywidualną sprawę konkretnego podmiotu". W postanowieniu z dnia 6 lutego 2008 r. ${ }^{20}$ NSA orzekł, iż „z reguł wykładni systemowej art. 12 ust. 1 u.i.o.ś., tj. zestawienia treści pkt 1 i 2 ust. 1 po-

15 Por. glosa do postanowienia Naczelnego Sądu Administracyjnego z dnia 28 lutego 2008 r., sygn. II OSK 216/08, „Zeszyty Naukowe Sądownictwa Administracyjnego", nr 6/2009, s. 153.

16 Por. postanowienie z dnia 28 lutego 2008 r., sygn. II OSK 216/08.

17 Por. wyrok z dnia 12 stycznia 2012 r., sygn. II SA/Kr 1437/11.

18 Wyrok z dnia 2 czerwca $2009 \mathrm{r}$.

19 Tj. Dz.U. z 2012 r., poz. 270 ze zm., dalej jako: p.p.s.a.

20 Sygn. II OSK 107/08. 
wyższego artykułu wynika jednoznacznie, że zarządzenie pokontrolne jest odrębną od decyzji administracyjnej prawną formą działania administracji". W cytowanym już wyroku z dnia 25 marca 2008 r. $^{21}$ WSA w Opolu wskazał, że „bezspornie zarządzenie pokontrolne, wydane na podstawie art. 12 ust. 1 pkt 1 u.i.o.ś. nie jest decyzją administracyjną, gdyż na gruncie art. 12 ust. 1 ustawy o Inspekcji Ochrony Środowiska ta forma działania została wyraźnie odróżniona przez ustawodawcę od decyzji, wymienionej pkt 2 tego przepisu. Nie jest również czynnością materialno-techniczną sensu stricto. Zarządzenie pokontrolne ma charakter władczy i rozstrzyga indywidualną kwestię konkretnego podmiotu, a zatem jest aktem, o jakim mowa w art. 3 $\S 2$ pkt 4 p.p.s.a.". Z kolei w uzasadnieniu wyroku z dnia 10 listopada 2010 r. ${ }^{22}$ WSA w Gliwicach wskazał, że „zarządzenia pokontrolne nie przybierają formy decyzji administracyjnej ani postanowienia, nie ma do nich zastosowania przepis art. $107 \S 3$ Kodeksu postępowania administracyjnego regulujący wymogi odnoszące się do obligatoryjnych elementów decyzji, w tym jej faktycznego i prawnego uzasadnienia".

Przedstawiciele doktryny również negują pogląd uznający zarządzenie pokontrolne za decyzję administracyjną. W. Radecki ${ }^{23}$ wskazuje, że jest to niewątpliwie czynność prawna wymagająca określonej formy pisemnej, ale nie decyzja. Zbieżne stanowisko prezentuje B. Draniewicz ${ }^{24}$. Natomiast zdaniem T. Czecha ${ }^{25}$ zarządzeniu pokontrolnemu brakuje jednej, podstawowej cechy decyzji administracyjnej, mianowicie nałożenie w drodze zarządzenia pokontrolnego obowiązku nie rozstrzyga merytorycznie samej sprawy administracyjnej, do której odnosiła się kontrola.

Skoro nie budzi wątpliwości, że zarządzenie pokontrolne będąc odrębną od decyzji administracyjnej prawną formą działania inspektora ochrony środowiska, uznawane jest za akt ad-

21 Sygn. II SA/Op 5/08.

22 Sygn. II SA/GL 618/10.

23 Por. W. Radecki, op. cit., s. 47-48.

24 Por. B. Draniewicz op. cit., s. 151.

25 Por. T. Czech, op. cit., s. 96. 
ministracji publicznej, o jakim mowa w art. $3 \S 2$ pkt 4 p.p.s.a., uwzględniając jednocześnie, że nie może być ono zakwestionowane $\mathrm{w}$ toku instancyjnym, należy przybliżyć zagadnienie dotyczące możliwości zaskarżenia takiego aktu do sądu ${ }^{26}$.

Przede wszystkim warto wskazać na zakres kognicji sądu administracyjnego. Zgodnie z art. $3 \S 1$ i 2 ustawy p.p.s.a., sądy administracyjne sprawują kontrolę działalności administracji publicznej i stosują środki określone w ustawie. Kontrola działalności administracji publicznej przez sądy administracyjne obejmuje orzekanie w sprawach skarg na:

1) decyzje administracyjne;

2) postanowienia wydane w postępowaniu administracyjnym, na które służy zażalenie albo kończące postępowanie, a także na postanowienia rozstrzygające sprawę co do istoty;

3) postanowienia wydane w postępowaniu egzekucyjnym i zabezpieczającym, na które służy zażalenie;

4) inne niż określone w pkt 1-3 akty lub czynności z zakresu administracji publicznej dotyczące uprawnień lub obowiązków wynikających z przepisów prawa;

a) pisemne interpretacje przepisów prawa podatkowego wydawane w indywidualnych sprawach;

5) akty prawa miejscowego organów jednostek samorządu terytorialnego i terenowych organów administracji rządowej;

6) akty organów jednostek samorządu terytorialnego i ich związków, inne niż określone w pkt 5, podejmowane w sprawach z zakresu administracji publicznej;

7) akty nadzoru nad działalnością organów jednostek samorządu terytorialnego;

8) bezczynność organów w przypadkach określonych w pkt. 1-4a.

Zaskarżeniu do sądu administracyjnego na podstawie art. $3 \S 2$ pkt 4 p.p.s.a. podlegają wyłącznie akty lub czynności

26 Postępowanie sądowoadministracyjne oparte jest na zasadzie skargowości, co oznacza, że nie może być wszczęte z urzędu, a jedynie z inicjatywy uprawnionego podmiotu. 
inne niż określone w art. $3 \S 2$ pkt 1-3 tej ustawy, a więc nie mające charakteru decyzji lub postanowienia. Jednakże rozróżnienie decyzji administracyjnych od innych aktów podlegających kognicji sądowoadministracyjnej może w niektórych konkretnych sytuacjach nastręczać trudności.

W porównaniu do w art. 16 ust. 1 ustawy z dnia 11 maja 1995 r. o Naczelnym Sądzie Administracyjnym ${ }^{27}$ ustawodawca zrezygnował z wymogu, by zaskarżalna czynność dotyczyła przyznania, stwierdzenia albo uznania uprawnienia lub obowiązku. Zakres stosowania nowego uregulowania w doktrynie i orzecznictwie nie jest rozumiany jako daleko odbiegający od dawnego. Odnosi się najczęściej do czynności materialno-technicznych wywołujących, choćby pośrednio, określone skutki prawne dla strony ${ }^{28}$.

Przeprowadzenie ścisłej delimitacji obu grup aktów administracyjnych, a więc tych podlegających kognicji sądowoadministracyjnej na podstawie art. $3 \S 2$ pkt 1 lub pkt 4 p.p.s.a. jest skomplikowane ponieważ przyjęte kryteria ustawowe aktów lub czynności poddanych kognicji sądu na podstawie przepisu art. $3 \S 2$ pkt 4 p.p.s.a. mogą budzić trudności w praktycznej kwalifikacji danych form działania administracji. Artykuł $3 \S 2$ pkt 4 p.p.s.a. wskazuje natomiast możliwość zaskarżalności innej grupy aktów administracyjnych (nie będących decyzjami ani postanowieniami), które dotyczą uprawnień lub obowiązków wynikających z przepisów prawa. Przedmiotowy zakres aktów dotyczących uprawnień lub obowiązków wynikających z przepisów prawa należy ograniczyć do przepisów materialnego prawa administracyjnego, które wyłączają możliwość wydania decyzji czy postanowienia, ale wymagają od organu wykonującego administrację publiczną potwierdzenia obowiązku lub uprawnienia ${ }^{29}$.

27 Dz.U. nr 74, poz. 368 ze zm.

28 A. Kabat, [w:] B. Dauter, B. Gruszczyński, A. Kabat, M. Niezgódka-Medek, Prawo o postępowaniu przed sądami administracyjnymi, Komentarz, Warszawa 2011, s. 26-28.

29 Tak B. Adamiak, Z problematyki właściwości sądów administracyjnych (art. $3 \& 2$ pkt 4), ZNSA 2006, nr 2, s. 9-12. 
Należy zgodzić się ze stanowiskiem zaprezentowanym $\mathrm{w}$ orzecznictwie sądowoadministracyjnym ${ }^{30}$, że dany akt lub czynność powinny ustalać, stwierdzać, potwierdzać (lub nie) obowiązki określone przepisami prawa administracyjnego. Oznacza to, że rozstrzygnięcie administracyjne nakłada na stronę postępowania administracyjnego obowiązek określonego zachowania, który to obowiązek powinien być wyrażony precyzyjnie, bez niedomówień i możliwości interpretacji. Musi więc istnieć związek między ustaleniem, bądź potwierdzeniem określonego obowiązku lub uprawnienia (lub ich odmową), a możliwością realizacji takiego uprawnienia czy obowiązku wynikającego z przepisu prawa.

Podstawowe znaczenie dla przeprowadzenia przedmiotowej delimitacji między aktami dającymi się przyporządkować kognicji sądów administracyjnych na podstawie art. $3 \S 2$ pkt 1 lub 4 p.p.s.a. wydaje się mieć to, czy norma prawa administracyjnego wymaga konkretyzacji. $\mathrm{Z}$ obu grup należy natomiast bez wątpienia wyłączyć przepisy prawa, które kształtują uprawnienia lub obowiązki bezpośrednio z mocy prawa. Za przykład mogą służyć tu przepisy ustawy z dnia 24 września 2010 r. o ewidencji ludności ${ }^{31}$, które nakładają z mocy prawa obowiązki w zakresie zameldowania, wymeldowania oraz posiadania dowodu osobistego. Ukształtowanie treści obowiązków w tym zakresie wyłącza konieczność wydawania aktów administracyjnych ${ }^{32}$.

W orzecznictwie sądowym dominuje pogląd, że ustawodawca coraz częściej odchodzi od ukształtowania stosunków administracyjnoprawnych, zachodzących między państwem (jego organami), a obywatelami i innymi podmiotami admi-

30 Reprezentatywny dla tego stanowiska pogląd zaprezentowano w postanowieniu NSA z dnia 22 lutego 2012 r., sygn. I OSK 194/12, LEX nr 1115961.

31 Ustawa z dnia 24 września 2010 r. o ewidencji ludności (Dz.U. z 2010 r. Nr 217, poz. 1427), ustawa wejdzie w życie z dniem 1 stycznia 2015 r., za wyjątkiem art. 62, który wszedł w życie z dniem 1 stycznia 2013 r.

32 J. Drachal, J. Jagielski, J. Stankiewicz, [w:] Prawo o postępowaniu przed sądami administracyjnymi, Komentarz, pod red. R. Hausera i M. Wierzbowskiego, Warszawa 2013 r., s. 62. 
nistrowanymi, w drodze decyzji administracyjnej, na rzecz uprawnień i obowiązków wynikających bezpośrednio z przepisów prawa ${ }^{33}$. W takich przypadkach do konkretyzacji prawnego stosunku administracyjnego nie jest wymagane rozstrzygnięcie w formie decyzji administracyjnej. Mogą pojawić się tu akty lub czynności podejmowane przez organy administracji publicznej, których przedmiotem jest przyznanie (odmowa przyznania), stwierdzenie (odmowa stwierdzenia) albo uznanie (odmowa uznania) określonego uprawnienia lub obowiązku, wynikających z mocy powszechnie obowiązującego przepisu prawa. Podmiot, którego uprawnienia lub obowiązku dotyczy akt lub czynność, o których mowa w art. $3 \S 2$ pkt 4 p.p.s.a. ma zapewnioną ochronę na drodze sądowej, ponieważ może zaskarżyć takie akty i czynności organu administracji publicznej do sądu administracyjnego, a także bezczynność organu w tych sprawach, jak również żądać, aby sąd administracyjny orzekł o istnieniu lub nieistnieniu uprawnienia lub obowiązku wynikających z przepisów prawa (art. 146 p.p.s.a.). Właśnie to, że istnienie lub nieistnienie uprawnienia lub obowiązku wynika z przepisów prawa, wyraźnie wskazuje, że chodzi tu o uprawnienie lub obowiązek określonej osoby (podmiotu administrowanego), których źródłem jest obowiązujący powszechnie przepis prawny ${ }^{34}$.

Ze względu na użyte w ustawie p.p.s.a. kryteria, trudno dokładnie scharakteryzować tę kategorię działań administracji publicznej, jaką określono w art. $3 \S 2$ pkt 4 p.p.s.a. Niemniej zgodzić się należy z poglądem, według którego, że „są to akty lub czynności, które:

1) mają charakter władczy, chociaż nie mają charakteru decyzji lub postanowienia, te bowiem są zaskarżalne na podstawie art. $3 \S 2$ pkt $1-3$ p.p.s.a.;

33 Uchwała 5 sędziów NSA z dnia 23 czerwca 1997 r., OPK 1/97, publ. ONSA z 1997 r., z. 4, poz. 149; uch. 7 sędziów NSA z dnia 4 lutego 2008 r., I OPS 3/07.

34 Zob. wyrok WSA w Poznaniu z dnia 19 maja 2011 r., sygn. II SA/Po 114/11, LEX nr 1132363. 
2) są podejmowane w sprawach indywidualnych ${ }^{35}$, ponieważ akty o charakterze ogólnym zostały wymienione w art. $3 \S 2$ pkt 5 i 6 p.p.s.a.;

3) muszą mieć charakter publicznoprawny, ponieważ tylko w tym zakresie działalność administracji została poddana sądowej kontroli;

4) dotyczą uprawnień lub obowiązków wynikających z przepisów prawa; oznacza to, że musi istnieć ścisły i bezpośredni ${ }^{36}$ związek między działaniem (zaniechaniem określonego działania) organu administracji, a możliwością realizacji uprawnienia (obowiązku) wynikającego z przepisu prawa przez podmiot niepowiązany organizacyjnie z organem wydającym dany akt lub podejmującym daną czynność" 37 .

W praktyce rzeczywisty zakres aktów lub czynności z art. 3 $\S 2$ pkt 4 p.p.s.a. kształtowany jest przez orzecznictwo, przy czym dostrzec trzeba, że dominują orzeczenia wskazujące, jakie działania administracji nie są aktami lub czynnościami ze wskazanego wyżej przepisu. Coraz częściej jednak występują orzeczenia kwalifikujące poszczególne działania organów administracji jako należące do tej kategorii ${ }^{38}$.

$\mathrm{Z}$ taką sytuacją mamy do czynienia w przypadku omawianego zarządzenia pokontrolnego organów Inspekcji Ochrony Środowiska. W orzecznictwie ugruntowane jest już stanowisko kwalifikujące ten akt, jako akt, o którym mowa w art. $3 \S 2$ pkt 4 p.p.s.a. Bezspornie zarządzenie pokontrolne, wydane na podstawie art. 12 ust. 1 pkt 1 ustawy o Inspekcji Ochrony Środowiska nie jest decyzją administracyjną, gdyż na gruncie

35 Odmienne stanowisko prezentuje M. Jaśkowska; patrz M. Jaśkowska, Właściwość sądów administracyjnych (zagadnienia wybrane), [w:] J. Zimmerman (red.), Koncepcja systemu prawa administracyjnego, Warszawa 2007.

36 Pogląd ugruntowany w orzecznictwie, jednakże w doktrynie występują odmienne stanowiska; zaprezentowane w: J. Drachal, J. Jagielski, J. Stankiewicz, op. cit., s. 64.

37 Tak J. P. Tarno, Prawo o postępowaniu przed sądami administracyjnymi, Komentarz, Warszawa 2010 r., s. 28, 29; zob. wyrok WSA w Olsztynie z 20 września 2006 r., sygn. II SA/Ol 456/06.

38 Por. J. P. Tarno, op. cit., s. 28-29. 
art. 12 ust. 1 ustawy o Inspekcji Ochrony Środowiska ta forma działania została wyraźnie odróżniona przez ustawodawcę od decyzji, wymienionej w pkt 2 tego przepisu. Nie jest również czynnością materialno-techniczną sensu stricto. Zarządzenie pokontrolne rozstrzyga indywidualną kwestię konkretnego podmiotu, jednocześnie przepisy u.i.o.ś. nie przewidują możliwości jego zaskarżenia do organu wyższego stopnia, a zatem jest ono aktem, o jakim mowa w art. $3 \S 2$ pkt 4 p.p.s.a. i z tego względu podlega zaskarżeniu do sądu administracyjnego ${ }^{39}$.

W związku z przedstawioną wyżej kwalifikacją prawną zarządzenia pokontrolnego wydawanego na podstawie art. 12 ust. 1 u.i.o.ś., należy przyjąć, że podlega ono kognicji sądu administracyjnego na podstawie art. $3 \S 2$ pkt 4 p.p.s.a. jako inny akt z zakresu administracji publicznej. Sąd administracyjny jako tzw. „sąd prawa” bada taki akt pod względem legalności czyli zgodności z prawem. Badanie zaś legalności zaskarżonego zarządzenia pokontrolnego w praktyce powoduje konieczność stwierdzenia przez sąd, czy organ IOŚ dysponował wystarczającymi ustaleniami, które pozwalały mu na wydanie zarządzenia, czy naruszenia zostały stwierdzone w prawidłowy sposób, czy są dostatecznie określone i wyjaśnione. Sąd zobowiązany jest zatem ustalić, czy istniały podstawy do wydania zarządzenia o takiej, a nie innej treści.

Wniesienie do sądu administracyjnego skargi na takie zarządzenie podlega reżimowi wynikającemu z art. $52 \S 3$ p.p.s.a., zawierającemu wymóg uprzedniego wezwania na piśmie właściwego organu w terminie czternastu dni od dnia, w którym skarżący dowiedział się lub mógł się dowiedzieć o wydaniu aktu do usunięcia naruszenia prawa. Stosownie natomiast do art. 53 $\S 2$ p.p.s.a., w przypadku, o którym mowa w art. $52 \S 3$ tej ustawy, skargę wnosi się w terminie trzydziestu dni od dnia dorę-

39 Wyrok Naczelnego Sądu Administracyjnego z dnia 2 czerwca 2009 r., sygn. II GSK 1009/08, publ. ONSAiWSA 2010/5/86; postanowienie Naczelnego Sądu Administracyjnego dnia 6 lutego 2008 r., sygn. II OSK 107/08; postanowienie NSA z dnia 28 lutego 2008 r., sygn. akt II OSK 216/08; wyrok Wojewódzkiego Sądu Administracyjnego w Krakowie z dnia 12 stycznia 2012 r., sygn. II SA/Kr 1437/11. 
czenia odpowiedzi organu na wezwanie do usunięcia naruszenia prawa, a jeżeli organ nie udzielił odpowiedzi na wezwanie, w terminie sześćdziesięciu dni od dnia wniesienia wezwania o usunięcie naruszenia prawa.

Wezwanie do usunięcia naruszenia prawa stanowi nadzwyczajny środek zaskarżenia. Wezwanie to nie stanowi realizacji zasady dwuinstancyjności postępowania administracyjnego. Jest to niejako środek stanowiący surogat zaskarżenia wynikającego z przepisów ustaw procesowych, którego istotą i celem jest wykreowanie dodatkowych możliwości autorewizji działania organu administracji publicznej, który podjął akt lub dokonał kwestionowanej czynności, przeciwko którym ma być wniesiona skarga ${ }^{40}$.

Artykuł $52 \S 3$ p.p.s.a. przewidujący obowiązek dokonania wezwania określa jednocześnie minimum wymogów procesowych, jakie muszą zostać spełnione dla zakwalifikowania danego zachowania jako spełniającego przesłanki wezwania do usunięcia naruszenia prawa. Wymogami tymi są forma pisemna oraz konieczność wniesienia wezwania w terminie 14 dni od dnia, w którym skarżący dowiedział się lub mógł się dowiedzieć o wydaniu aktu lub podjęciu czynności ${ }^{41}$.

W orzecznictwie funkcjonują dwa odrębne poglądy co do tego czy czternastodniowy termin, jest terminem prawa procesowego, czy też terminem prawa materialnego.

Według jednego z nich o tym, czy mamy do czynienia $\mathrm{z}$ terminem prawa materialnego, czy procesowego przesądza cel jakiemu dany termin służy. W przypadku gdy celem tym jest kształtowanie praw i obowiązków podmiotów w ramach stosunku prawnego wyznaczonego przepisami prawa materialnego terminy, po których upływie następuje wygaśnięcie praw lub obowiązków materialnoprawnych, czy niemożność uzyskania takich praw lub nałożenia obowiązków, mają charakter terminów prawa materialnego. Terminami prawa procesowego są natomiast terminy wyznaczone do dokonania czynności procesowych. Taką też czynnością niezbędną z punktu widzenia

40 Postanowienie NSA z dnia 6 lipca 2010 r., sygn. II OSK 1199/10.

41 Postanowienie NSA z dnia 4 stycznia 2011 r., sygn. I OSK 2023/10. 
skutecznego złożenia skargi do sądu administracyjnego jest skorzystanie wcześniej ze środka zaskarżenia zwykłego albo nadzwyczajnego, wprowadzonego do p.p.s.a. w celu stworzenia organowi możliwości autorewizji swojego działania i ograniczenia obciążania sądu sprawami, które mogą być załatwione przez organy administracji ${ }^{42}$.

Wskazuje się również, że termin do wniesienia wezwania do usunięcia naruszenia prawa jest terminem prawa materialnego i jako taki nie podlega przywróceniu. Jego upływ wyłącza więc możliwość zaskarżenia aktu lub czynności do sądu administracyjnego ${ }^{43}$.

Skoro zatem przepisy ustawy o Inspekcji Ochrony Środowiska uprawniają wskazane $\mathrm{w}$ nich organy do wydawania zarządzeń pokontrolnych w oparciu o wyniki dokonywanych kontroli, a jednocześnie nie przewidują środka zaskarżenia tego zarządzenia do organu wyższego stopnia, to zarządzenie pokontrolne, stwierdzające istnienie po stronie obywatela jakiegoś obowiązku, podlega zaskarżeniu do sądu na podstawie art. 3 $\S 2$ pkt 4 p.p.s.a. Skarga do sądu może zostać wniesiona w trybie art. $52 \S 3$ i $53 \S 2$ p.p.s.a. ${ }^{44}$

Stosownie więc do art. $52 \S 3$ p.p.s.a. przed złożeniem skargi na zarządzenie pokontrolne organów Inspekcji Ochrony Środowiska należy wezwać na piśmie organ Inspekcji Ochrony Środowiska, który wydał zarządzenie pokontrolne, do usunięcia naruszenia prawa. Istota wezwania sprowadza się do umożliwienia organowi dobrowolnego usunięcia nieprawidłowości. Wezwanie nie potwierdza uprawnień lub obowiązków określonych przepisami prawa. Określa jedynie uchybienia i zobowiązuje do ich niezwłocznego usunięcia ${ }^{45}$.

42 Zob. wyrok Naczelnego Sądu Administracyjnego z 6 lipca 2011 r., sygn. I FSK 1063/10; wyrok Naczelnego Sądu Administracyjnego z 14 marca 2011 r., sygn. I FPS 5/10.

43 J. P. Tarno, op. cit., s. 160-161.

44 Postanowienie Naczelnego Sądu Administracyjnego z dnia 28 lutego 2008 r., sygn. II OSK 216/08, LEX nr 533652; B. Draniewicz, op. cit., s. 151.

45 Tak w postanowieniu Wojewódzkiego Sądu Administracyjnego w Białymstoku z dnia 17 maja 2012 r., sygn. II SA/Bk 67/12. 
Jeśli skarżący nie wezwie organu do usunięcia naruszenia prawa to nie wypełni obowiązku wynikającego z przepisu art. $52 \S 3$ p.p.s.a. Wniesienie skargi do sądu administracyjnego będzie w takiej sytuacji niedopuszczalne. Skargę można bowiem wywieść po wyczerpaniu środków zaskarżenia, jeżeli służyły skarżącemu w postępowaniu przed właściwym organem (art. $52 \S 1$ p.p.s.a.). Niewypełnienie powyższego obowiązku, będzie skutkować odrzuceniem skargi na podstawie art. $58 \S 1$ pkt 6 i $\S 3$ p.p.s.a. Ten sam skutek będzie miał miejsce w przypadku wniesienia skargi z naruszeniem terminów przewidzianych do jej wywiedzenia. Wówczas sąd odrzuci skargę na podstawie art. $58 \S 1$ pkt 2 p.p.s.a. ${ }^{46}$ Skargę należy wnieść bowiem $\mathrm{w}$ terminie trzydziestu dni od dnia doręczenia odpowiedzi organu na powyższe wezwanie, a jeżeli organ nie udzielił odpowiedzi na wezwanie - $\mathrm{w}$ terminie sześćdziesięciu dni od dnia wniesienia wezwania. Skargę do sądu wnosi się za pośrednictwem organu Inspekcji Ochrony Środowiska, który wydał zaskarżone zarządzenie pokontrolne (art. $54 \S 1$ p.p.s.a.).

Termin do wniesienia skargi jest terminem ustawowym, a więc niedopuszczalne jest jego skrócenie lub przedłużenie ani przez sąd, ani tym bardziej przez organ administracyjny. Przepisy Kodeksu postępowania administracyjnego nie mają co do tego terminu zastosowania, a zatem przedłużenie terminu do udzielenia odpowiedzi na wezwanie do usunięcia naruszenia prawa przez organ administracyjny na podstawie przepisu art. $36 \S 1$ k.p.a. pozostawałoby bez wpływu na bieg terminu

46 Patrz postanowienie Wojewódzkiego Sądu Administracyjnego w Poznaniu z dnia 5 listopada 2009 r., sygn. II SA/Po 745/09; podobnie: postanowienie Wojewódzkiego Sądu Administracyjnego w Gliwicach z dnia 16 kwietnia 2012 r., II SA/GL 382/11; postanowienie Wojewódzkiego Sądu Administracyjnego w Łodzi z dnia 23 marca 2012 r., sygn. II SA/Łd 146/12; postanowienie Wojewódzkiego Sądu Administracyjnego w Bydgoszczy z dnia 21 lipca 2010 r., sygn. II SA/Bd 488/10; postanowienie Wojewódzkiego Sądu Administracyjnego w Gliwicach z dnia 7 stycznia 2009 r., sygn. II SA/Gl 1150/08; postanowienie Wojewódzkiego Sądu Administracyjnego w Poznaniu z dnia 27 listopada 2008 r., sygn. II SA/Po 852/08; postanowienie Wojewódzkiego Sądu Administracyjnego w Opolu z dnia 30 września 2008 r., sygn. II SA/Op 176/08; postanowienie Wojewódzkiego Sądu Administracyjnego w Gdańsku z dnia 11 września 2007 r., sygn. II SA/Gd 508/07. 
60-dniowego do wniesienia skargi do sądu administracyjnego. $\mathrm{Z}$ analizy przepisu art. $53 \S 2$ p.p.s.a wynika, że już z dniem wniesienia wezwania do usunięcia naruszenia prawa rozpoczyna bieg termin 60 dni na wniesienie skargi, mimo że sprawa udzielenia odpowiedzi na to wezwanie jest otwarta. W okresie biegu tego terminu organ może udzielić odpowiedzi na wezwanie i w takim wypadku dalszy bieg terminu staje się bezprzedmiotowy, ponieważ od dnia doręczenia odpowiedzi na wezwanie rozpoczyna się bieg terminu 30-dniowego. Jeżeli natomiast w tym okresie organ nie udzieli odpowiedzi na wezwanie, to nieprzerwanie biegnie termin 60 dni, liczony - jak już wspomniano - od dnia wniesienia wezwania ${ }^{47}$.

$\mathrm{Na}$ tle powyższych rozważań można sformułować wniosek, iż najistotniejsze jest to, że aby skutecznie zaskarżyć zarządzenie pokontrolne należy uprzednio wezwać organ Inspekcji Ochrony Środowiska do usunięcia naruszenia prawa. Tymczasem przepisy u.i.o.ś. nie wskazują, że zarządzenie pokontrolne powinno zawierać pouczenie o możliwości jego zaskarżenia do sądu administracyjnego, a przede wszystkim nie nakładają na organy Inspekcji Ochrony Środowiska szczegółowego przedstawienia trybu, jaki powinien być zachowany, aby skarga na zarządzenie została skutecznie wniesiona. Taki stan rzeczy budzi oczywiście sporo wątpliwości i wydaje się, że istniejące rozwiązania prawne nie rokują najlepiej dla skutecznego kwestionowania zarządzeń pokontrolnych. Można zaryzykować tezę, iż konieczna jest interwencja ustawodawcy w powyższym zakresie. Uzasadniony jest tym samym de lege ferenda postulat przyjęcia uregulowań jasno precyzujących tryb i drogę zaskarżania tego typu aktów.

Reasumując, zagadnienie będące tematem opracowania ma istotny wpływ na realizację praw jednostki w postępowaniu przed sądami administracyjnymi. Przyznanie podmiotowi korzystającemu ze środowiska, prawa zaskarżenia zarządzenia pokontrolnego, jest gwarancją poszanowania praw jednostki. Zasadniczym celem współczesnego sądownictwa administra-

47 Zob. uzasadnienie uchwały Składu Siedmiu Sędziów NSA z dnia 2 kwietnia 2007 r., sygn. II OPS 2/07, ONSA i WSA z 2007 r., nr 3, poz. 60. 
cyjnego jest bowiem ochrona praw podmiotowych jednostki w sferze prawa publicznego, którego prawo ochrony środowiska jest istotną częścią. Ustawodawca, wprowadzając możliwość zaskarżenia zarządzenia pokontrolnego, miał z pewnością na celu ochronę przed bezprawnym i nieuzasadnionym działaniem organów administracji publicznej. Zapewnienie obywatelom możliwości zaskarżenia zarządzenia pokontrolnego ma przede wszystkim wpływ na gwarancje swobód obywatelskich, a także na ochronę jednostki przed omnipotencją państwa i jego aparatu.

\section{BIBLIOGRAFIA}

Adamiak B., Z problematyki właściwości sądów administracyjnych, ZNSA 2006.

Drachal J., Prawo o postępowaniu przed sq̨dami administracyjnymi, Warszawa 2013.

Draniewicz B., Glosa do postanowienia Naczelnego Sądu Administracyjnego z dnia 28 lutego 2008 r., sygn. II OSK 216/08, ZNSA 2009.

Czech T., Zarządzenie pokontrolne organów Inspekcji Ochrony Środowiska, ZNSA 2011.

Jagielski J., Kontrola administracji publicznej, Warszawa 2007.

Kabat A., Prawo o postępowaniu przed sądami administracyjnymi, Warszawa 2011.

Piątek W., Postępowanie egzekucyjne w administracji, Warszawa 2011. Radecki W., Ustawa o Inspekcji Ochrony Środowiska, Wrocław 2000.

Tarno J. P., Prawo o postępowaniu przed sądami administracyjnymi, Warszawa 2010.

Kontakt e-mail:

73klim@gmail.com 